\begin{tabular}{ll}
$\overline{\text { 論 }}$ \\
\hline
\end{tabular}

\title{
起電力法による非化学量論的 $\mathrm{UO}_{2}-\mathrm{ThO}_{2}$ 固溶体の 熱力学的性質の測定*
}

\author{
田中皓** 木 村 悦 治*** \\ 山口昭 雄 ${ }^{* * * *}$ 森 山徐一郎 ${ }^{* * * *}$
}

Hiroshi Tanaka, Etsuji Kimura, Akio Yamaguchi and Joichiro Moriyama : Thermodynamic Properties of Non-Stoichiometric $\mathrm{UO}_{2}-\mathrm{ThO}_{2}$ Solid Solution by Electro-Motive Force Measurements. The thermodynamic properties of $\mathrm{UO}_{2}-\mathrm{ThO}_{2}$ solid solution of compositions $\left(\mathrm{U}_{y} \mathrm{Th}_{1-y}\right) \mathrm{O}_{2+x}$ with $y$ values of 0.295 to 0.048 and $x$ values below 0.029 were determined by emf measurements. The oxygen concentration cells were of the type

or $\mathrm{Pt} /$ air $/ \mathrm{ZrO}_{2}(+\mathrm{CaO}) /\left(\mathrm{U}_{y} \mathrm{Th}_{1-y}\right) \mathrm{O}_{2+*} / \mathrm{Pt}$

and operated in the temperature range 900 to $1050^{\circ} \mathrm{C}$.

$\mathrm{Pt} / \mathrm{Ni}, \mathrm{NiO} / \mathrm{ZrO}_{2}(+\mathrm{CaO}) /\left(\mathrm{U}_{y} \mathrm{Th}_{1-y}\right) \mathrm{O}_{2+x} / \mathrm{Pt}$

From the emf values and these temperature dependence, partial molar free energies, enthalpies and entropies of solution of oxygen in the solid solutions were calculated.

Between these partial molar quantities and the mean valence of $U$ ion in the solid solutions, there exist correlations which are nearly independent of the values of $y$. These results suggest that the non-stoichiometry of $\mathrm{UO}_{2}-\mathrm{ThO}_{2}$ solid solution is similar to that of $\mathrm{UO}_{2+z}$.

(Received August 10, 1971)

\section{I. 緒 言}

$\mathrm{UO}_{2}-\mathrm{ThO}_{2}$ 固溶体の熱力学的研究については, Anderson

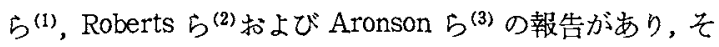
の $\mathrm{UO}_{2+x}$ に類似した非化学量論的性質を示すなど極めて 興味ある現象が観察されている。すなわち，固溶体中の酸 素の溶解の自由エネルギー变化，エンタルピー变化打よび エントロピー変化の值に扰よぼすThの効果を検討して みると，現在までに測定された組成においては， $\mathrm{UO}_{2+x}$ 中 に不活性な物質が単に固溶したような現象，い齐ゆる不活 性希彩效果 ${ }^{(4)}$ を示すことが認められている。この事実は， $\mathrm{UO}_{2}-\mathrm{ThO}_{2}$ 固溶体の非化学量論性が $\mathrm{UO}_{2+x}$ と同様のもので あることを示唆するものと考学られる。したがってこの固 溶体の非化学量論性をさらに詳しく観察することは，この ようなイオン結晶の非化学量論性についての一般的性質に 関する知見を得ることが出来るかもしれない，そこで著者 らは現在までに湘定されていないところの酸素量の少な

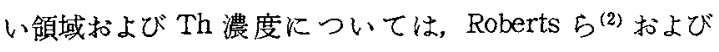

** 京都大学大学院(Graduate School, Kyoto University, Kyoto)

*** 京都大学大学院, 現在: 三菱金属鉱業株式会社 (Graduate School, Kyoto University, Kyoto. Present address : Mitsubishi Metal Mining Co., Ltd., Tokyo)

**** 京都大学工学部佁金学教室 (Department of Metallurgy, Faculty of Engineering, Kyoto University, Kyoto)

* 1971年 4 月本会東京大会に発表
Aronson ら ${ }^{(3)}$ の測定したるのの中間領域において，起電力 法を用いて固溶体中の酸素の溶解の自由エネルギー变化お よびェントロピー変化の値を測定し， $\mathrm{UO}_{2+\infty}$ を含む在来の 結果と比較し，この固溶体の非化学量論性について検討を 行なった。

\section{II. 実 験 原 理}

電解質として $\mathrm{CaO} て ゙$ 安定化された $\mathrm{ZrO}_{2}$ を用い，次に示 すような固体電池を構成した。

$$
\begin{aligned}
& \mathrm{Pt} / \mathrm{Air}\left(P_{\mathrm{O}_{2}}=0.21 \mathrm{~atm}\right) / \mathrm{ZrO}_{2}(+15 \mathrm{~mol} \% \mathrm{CaO}) / \\
& \left(\mathrm{U}_{y} \mathrm{Th}_{1-y}\right) \mathrm{O}_{2+x} / \mathrm{Pt} \\
& \mathrm{Pt} / \mathrm{Ni}, \mathrm{NiO} / \mathrm{ZrO}_{2}(+15 \mathrm{~mol} \% \mathrm{CaO}) / \\
& \left(\mathrm{U}_{y} \mathrm{Th}_{1-y}\right) \mathrm{O}_{2+x} / \mathrm{Pt}
\end{aligned}
$$

(2)の構成のものは主として低酸素濃度のものに使用し た.これは，(1)の構成を用いると起電力値が大きいため に電池回路を閉じたときに生ずる酸素移行による組成变動 を出来るだけ防止する意味と，電解質壁自体を通過する酸 素量を出来るだけ少なくする意味からである.(1)，(2)に

(1) J.S.Anderson et al. : J.Chem. Soc. (London) , 3 (1959), 3324.

(2) L.E.J. Roberts et al. : Proc.of the Second (I.N. International Conf.on the Peaceful Uses of Atomic Energy, 28 (1958), 215.

(3) S. Aronson and J.C.Clayton: J. Chem. Phys., 32 (1960), 749 .

(4) L. E. J. Roberts and T. L. Markin : Proc. Brit. Ceram.Soc., 8(1967), 201. 
示すよらな酸素濃淡電池の与える平衡起電力値を $E$ とす れば，次に示すよらな(3)式が成立する.

$$
\begin{aligned}
E & =-(1 / 4 \boldsymbol{F}) \int_{\mu_{\mathrm{O}_{2}}^{\mathrm{I}}}^{\mu_{\mathrm{O}_{2}}^{\mathrm{I}}} t_{\text {ion }} d \mu_{\mathrm{O}_{2}} \\
& =-(R T / 4 \boldsymbol{F}) \ln \left(P_{\mathrm{O}_{2}}^{\mathrm{I}} / P_{\mathrm{O}_{2}}^{\mathrm{I}}\right)
\end{aligned}
$$

ただし

$\boldsymbol{F}:$ ファラデー定数, $T$ : 絶対温度, $R$ : 気体定数, $\mu_{\mathrm{O}_{2}}^{\mathrm{I}}, \mu \mathrm{O}_{9}$ : 左右各極での酸素の化学ポテンシャル, $P_{\mathrm{O}_{2}}^{\mathrm{I}}, P_{\mathrm{O}_{2}}^{\mathrm{II}}$ : 左右各極での酸素分圧, $t_{\mathrm{ion}}$ : 酸素イオンの輸 率, 本実験の条件では $t_{\mathrm{o}^{2}}=1$ とおける。

(1), (2)の電池において, 照合電極である左極の酸素 ポテンシャル值が既知なので, (3) 式から, 測定起電力值 を用いて固溶体の平衡酸素ポテンシャル值を次の $(4)$ 式に 示すように計算することが出来る.

$$
\Delta \bar{G}\left(\mathrm{O}_{2}\right)=-4 E \boldsymbol{F}+R T \ln P_{\mathrm{O}_{2}}^{\mathrm{I}}
$$

また, 固容体中の酸素の溶解のエントロピー変化および エンタルピー変化は, 次の $(5),(6)$ 式にしたがって計算 された。

$$
\begin{aligned}
\Delta \bar{S}\left(\mathrm{O}_{2}\right) & =-\left(\partial \Delta \bar{G}\left(\mathrm{O}_{2}\right) / \partial T\right) \\
& =4 \boldsymbol{F}(\partial E / \partial T)-R \ln P_{\mathrm{O}_{2}}^{\mathrm{I}} \\
\Delta \bar{H}\left(\mathrm{O}_{2}\right) & =\Delta \bar{G}\left(\mathrm{O}_{2}\right)+T \Delta \bar{S}\left(\mathrm{O}_{2}\right)
\end{aligned}
$$

ここに, $P_{\mathrm{O}}^{\mathrm{I}}$ は $(1),(2)$ の電池の左極の示寸平衡酸素 分圧である.

\section{III. 実験方法および操作}

\section{1. 試料調製}

固溶体は別報(5)で述べたように共沈法により，U/Th 比 で, 29.5/70.5, 24.5/75.5, 19.6/80.4, 9.8/90.2 および $4.8 / 95.2$ に相当するものを調製した. $1350^{\circ} \mathrm{C}$ で焼結後, $800^{\circ} \mathrm{C}$ で水素還元処理を行なったものを出発試料とした. この出発試料をそのままの状態であるいは, 適当量酸化さ せて，それを石英管に真空封入し， $800^{\circ} \mathrm{C}$ で約 1 週間かけ て焼鈍をかねた均一化処理を行なったものを実験に供し た. また一部の試料は $1350^{\circ} \mathrm{C}$ の焼結後, $800^{\circ} \mathrm{C}$ で約 1 週 間, 焼鈍を行ない, ついで水素還元し，それを，y の值の異 なるものと一緒に同一の石英管に封入し, $950^{\circ} \mathrm{C}$ で約 20 時 間加熱処理したものを実験に供した。

照合電極の一部として用いた， $\mathrm{Ni}+\mathrm{NiO}$ 混合体は， $\mathrm{Ni}$, $\mathrm{NiO}$ の各粉末を混合し，それを $4 \mathrm{t} / \mathrm{cm}^{2}$ の圧力で $12 \mathrm{~mm} \phi$, 厚さ3〜4 mm の圧粉体に成型し，それを約 $1100^{\circ} \mathrm{C}$ ，アル ゴンガス雲囲気下で焼結を行なって得た。

\section{2. 電池系および起電力測定}

電池の構成部分を Fig.1 に図示した。電解質としては, 一端を平らな底で封じたパイプ状の $\mathrm{CaO} て ゙$ 安定化された $\mathrm{ZrO}_{2}$ の焼結体 (日本化学陶業および Zircoa 社 (米国) 製) を

（5）田中, 木村, 山口, 森山：金属学会誌, 36 (1972), 183.

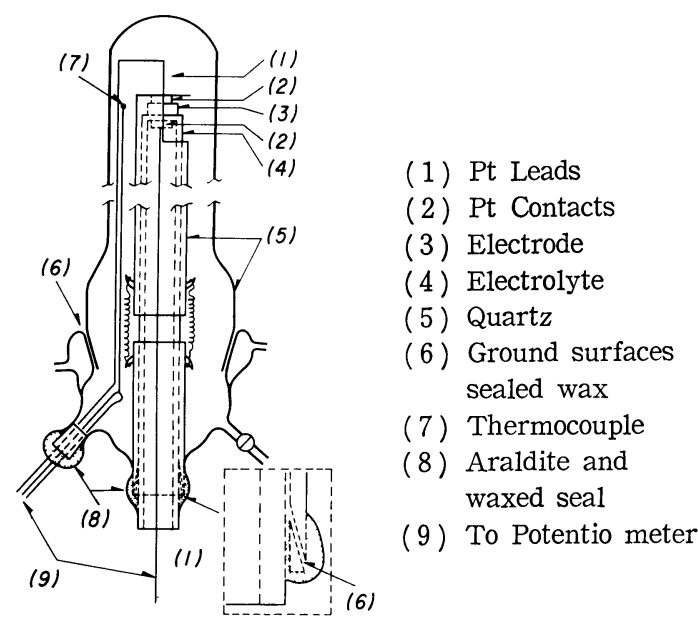

Fig.1 Cell assembly in reaction tube

用いた。ペレット状の試料表面を十分研摩後，Fig.1 亿図 示したように, 透明石英製反応管内に電池系を設置し, 室温 で真空処理を行なった後，脱酸アルゴンガス $\left(P_{\mathrm{O}_{2}}<10^{-15}\right.$ atm)を反応管内に導入して封じこんだ。このような操作 についで, 電池系を電気炉を用いてまず $950^{\circ} \mathrm{C}$ 程度に加 熱し，その温度で約 5 時間保持した後, $900 \sim 1050^{\circ} \mathrm{C}$ の温 度範囲で，昇降温を繰返してポテンショメーターを用いて 起電力値を測定した。

起電力値は 1 時間で $\pm 0.1 \mathrm{mV}$ 以下の変動に止まる点を もって平衡に達したものとした．各平衡起電力値を得るに は約 $3 \sim 4$ 時間程度を要した。電池は最初の平衡起電力値 を得てから，約 20 時間程度稼動させたが，その測定期間 中, 起電力値の再現性は本実験の誤差範囲内 $( \pm 0.5 \mathrm{mV})$ で 十分満足すべきものと認められた。

\section{3. 固溶体中の過剩酸素量 $\boldsymbol{x}$ の測定}

起電力の測定終了後, 試料を反応管内で約 $10 \sim 30^{\circ} \mathrm{C} / \mathrm{min}$ の速度で泠却させ，室温で反応管より取り出した後ただち に精密級化学天秤を用いてその重量を測定した。 その後熱 天科を用いて $800^{\circ} \mathrm{C} て ゙$ 水素還元を行ない，重量変化が認め られなくなった時点で, 試料を反応管の室温部分までつり 上げて冷却させ，それを精密級化学天科を用いて重量を測 定し，還元処理による重量変化から $x$ の值を計算した，本 実験で得られた $x$ の值の推定誤差は \pm 0.0006 と計算され た. ところで水素還元処理に対応する場合を $x=0$ と仮定 したことについては $y$ の值により還元後の $x$ の值が異な ることが考觉られが，この条件では $x$ の值自体が非常に 小さいことから，yによる差は誤差範囲内に十分入るもの と推定される. 一方, 水素還元処理により固溶体が亜化学 量論組成になることも考兄られるが，この場合には，本実 験で得られた $x$ の值は，実際より大きいものを表わすこと になる. しかしこの点については, よくわかっていないの 
で，本実験では従来より同じ采に用いられている方法を採 用し(2)(3)(6)，これらによる誤差は無視出来るとした。

\section{IV. 実 験 結 果}

Figs. 2, 3， 4 に電池 (1) の構成で示す平衡起電力値の温 度依存性を図示した。この場合, 電池 (2)の構成で測定し 得られた起電力值は $(7)$ 式の関係 ${ }^{(7)}$ を用いて電池 $(1)$ の構 成の場合の起電力值へ変換した.

$$
\Delta \bar{G}\left(\mathrm{O}_{2}\right)_{\mathrm{Ni}-\mathrm{NiO}}=-112470+41.16 \mathrm{~T} \mathrm{cal} / \mathrm{mol}
$$

Figs.2, 3, 4 でみられるよ5に, 各試料共, 起電力値の温 度依存性は注涪淔線とみなされた。また水素還元後同一の 石英管内に封入して処理を行なった試料については，士1 $\mathrm{mV}$ 以下の誤差で, $\boldsymbol{y}$ の值によらず起電力值およびその温 度依存性が，注ぼ一致するといら現象が観察された。これ らの得られた起電力值およびその温度依存性の結果から， (4)，(5)，(6)式を用いて固溶体中の酸素の溶解の相対 部分モル量が計算されたが，それらの $1250^{\circ} \mathrm{K}$ での值を

Table 1 にまとめて示した.

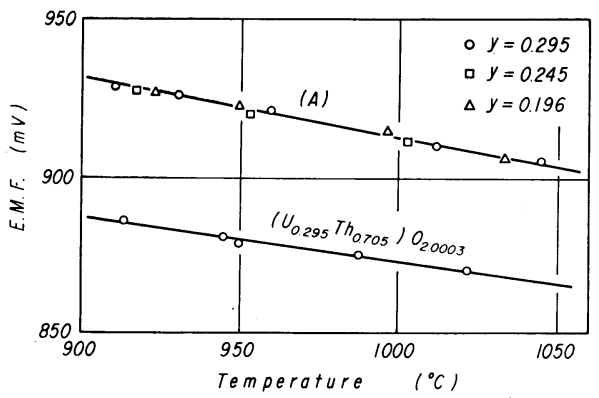

Fig.2 Results of E.M.F.measurements at various temperatures for cell (1)

A : Heat treated in a quarz capsule together with different $y$ specimens after reduction by hydrogen

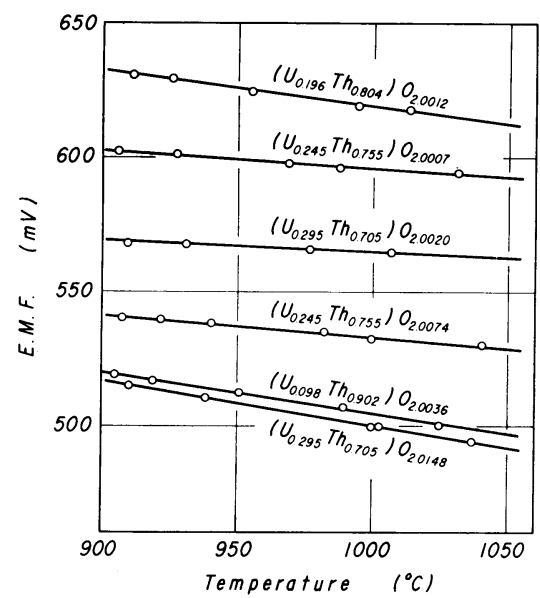

Fig.3 Results of E.M.F. measurements at various temperatures for cell (1)

(6) I. Cohen and R.M. Berman : J. Nuc. Mat., 18 (1966) , 77.

（7）大石，森山：未発表，投稿予定.

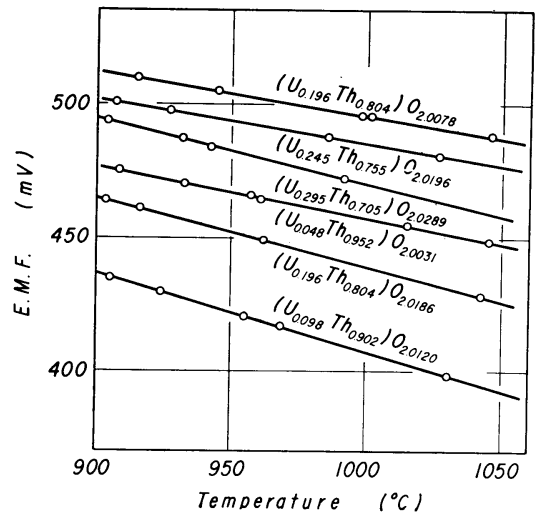

Fig.4 Results of E.M.F. measurements at various temperatures for cell (1)

Table 1 Partial molar free energies, enthalpies and entropies of solution of oxygen in $\left(\mathrm{U}_{y} \mathrm{Th}_{1-y}\right) \mathrm{O}_{2+x}$ at $1250^{\circ} \mathrm{K}$

\begin{tabular}{c|c|c|r|r}
\hline \hline$y$ & $\begin{array}{c}x \\
( \pm 0.0006)\end{array}$ & $\begin{array}{r}-\Delta \bar{G}\left(\mathrm{O}_{2}\right) \\
\mathrm{kcal} / \mathrm{mol}\end{array}$ & $\begin{array}{r}-\Delta \bar{H}\left(\mathrm{O}_{2}\right) \\
\mathrm{kcal} / \mathrm{mol}\end{array}$ & $\begin{array}{r}-\Delta \bar{S}\left(\mathrm{O}_{2}\right) \\
\mathrm{e} . \mathrm{u} . / \mathrm{mol}\end{array}$ \\
\hline 0.295 & $0.0002^{*}$ & 89.5 & 107.0 & 14 \\
0.295 & $0.0003^{* *}$ & 84.7 & 97.2 & 10 \\
0.295 & 0.0020 & 56.1 & 57.4 & 1 \\
0.295 & 0.0148 & 50.4 & 65.4 & 12 \\
0.295 & 0.0289 & 47.9 & 71.6 & 19 \\
0.245 & $0.0001^{*}$ & 89.4 & 106.9 & 14 \\
0.245 & 0.0007 & 59.0 & 62.8 & 3 \\
0.245 & 0.0074 & 53.3 & 59.5 & 5 \\
0.245 & 0.0196 & 49.0 & 64.0 & 12 \\
0.196 & $0.0001 *$ & 89.5 & 107.0 & 14 \\
0.196 & 0.0012 & 61.4 & 72.6 & 9 \\
0.196 & 0.0078 & 50.0 & 65.0 & 12 \\
0.196 & 0.0186 & 45.0 & 71.2 & 21 \\
0.098 & 0.0036 & 50.8 & 64.5 & 11 \\
0.098 & 0.0120 & 42.1 & 72.1 & 24 \\
0.048 & 0.0031 & 46.5 & 62.7 & 13 \\
\hline
\end{tabular}

* Heat treated in a quarz capsule together with different $y$ specimens after reduction by hydrogen

** Slight oxidation of $x=0.0002$ by short circuit of cell

\section{V. 考、察}

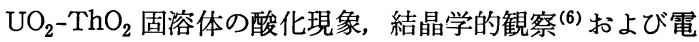

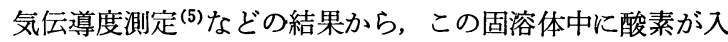
り込む際に $U^{4+}$ イオンが $\mathrm{U}^{5+}$ イオンに酸化され，格子間 侵入酸素イオンを形成するとい5反応が生ずると考えられ る.このことは,たとえば Cohen ら ${ }^{(6)}$, Anderson ら ${ }^{(1)}$ が格 子定数と過剩酸素量との関係をしらべた結果, 固溶体中の Uイオンの平均原子価の値, 寸なわち $(4+2 x / y)$ が 4 から 5 までは, 格子定数は過剩酸素量 $x$ の増加に対して減少を 示すが， 5 以上からは異常に增加するといらことを認めて いる. これは平均原子価が 4 から 5 までは， $\mathrm{U}^{5+}$ イオンの 形成を， 5 以上では $\left(\mathrm{UO}_{2}\right)^{2+}$ といらイオングループの形成 を示唆している。 またCohen ら ${ }^{(6)}$ は，近赤外吸收を用い $\tau\left(\mathrm{U}_{0.301} \mathrm{Th}_{0.699}\right) \mathrm{O}_{2+x}$ の $x$ の変化に伴ら Uイオンの変化に ついて観察しているが，この結果によると，平均原子価 4.02 から少なくとも 4.7 程度までは, U $\mathrm{U}^{5+}$ の形成だけで 
あると認めている，その他電気伝導度測定 ${ }^{(5)}$ の結果から も，4.02 から少なくとも 4.3 程度までは $\mathrm{U}^{5+}$ の形成だけ であるといえる．以上の結果から，Uの平均原子価が 5 に 達しない条件で, $\mathrm{U}^{5+}, \mathrm{O}_{i}^{2-}$ (格子間侵入酸素イオン)などの 欠陥同士が相互作用を汪とんど持たないと仮定すれば, $\mathrm{UO}_{2}-\mathrm{ThO}_{2}$ 固溶体の酸化は次の $(8)$ 式に示されるような形 になるであろら ${ }^{(3)}$.

$$
\mathrm{O}_{2} \text { (gas) }+4 \mathrm{U}^{4+}+2 i . s .=2 \mathrm{O}_{i}^{2-}+4 \mathrm{U}^{5+}
$$

ただし，i.s.は格子間侵入位置を表わす.

Aronson ら (3) はこの見地から, $\mathrm{UO}_{2}-\mathrm{ThO}_{2}$ 固溶体中の酸 素の溶解のエントロピー変化に対し次の $(9)$ に示すような 関係式を提唱している。

$$
\begin{aligned}
\Delta \bar{S}\left(\mathrm{O}_{2}\right)= & -2 R \ln [x /(1-x)] \\
& -4 R \ln [2 x /(y-2 x)]+Q
\end{aligned}
$$

ここに, $Q$ : 気相の酸素が固溶体に入るときのエントロ ピー変化拈よび格子間侵入酸素イオンの振動エントロピー への寄与を含む項.

彼らは $Q$ の值として, $y=1.00,0.90$ に対し $-38 \mathrm{e} . \mathrm{u}$. $y=0.70,0.52,0.29$ に対し $-43 \mathrm{e} . \mathrm{u}$.を与えれば, $x$ の值が 約 0.02 以上では, 実測值は (9) 式を比較的よく満足する ことを認めている，xの低いところでは，Q の值が一定し なくなるが，前述の $x$ の範囲では，固溶体中の酸素の配置 のエントロピー変化は, $\mathrm{U}^{5+}-\mathrm{O}_{i}^{2-}-\mathrm{U}^{5+}$ 型の複合欠陷 ${ }^{(4)} に$ よりほぼ説明されることを示している. また $\Delta \bar{G}\left(\mathrm{O}_{2}\right), \Delta \bar{H}$ $\left(\mathrm{O}_{2}\right)$ についても同様の試みを行なったが ( 9 ) 式のような関 係は見出していない, ところで, 著者らは $\mathrm{UO}_{2}-\mathrm{ThO}_{2}$ 固溶 体の電気伝導度の酸素分圧依存性について観察したが(5), その結果この固溶体の非化学量論的性質の酸素分圧に対す る関係が，yの值に関係なく固溶体中の Uイオンの平均原 子価にほぼ依存し, かつそれが UO $\mathrm{U}_{2+x}$ と類似のものであ ると考えられることを認めた. このことは, $\mathrm{UO}_{2}-\mathrm{ThO}_{2}$ 固 溶体中の酸素の挙動が, 固溶体中の $\mathrm{U}^{5+}$ イオンの濃度に大 部分関係していることを示唆している. そこで, この見地 から, Aronson ら (3)が取扱った領域をも含め, さらに $x$ の 値の低い領域にわたって, 固溶体中の酸素の相対部分モル 量と固溶体中の $\mathrm{U}$ 平均原子価との関係を, $\mathrm{UO}_{2+x}$ につい ての起電力法による結果 (8) (9) を含めて検討を行なってみ た. その結果を, Figs.5, 6,7 に図示した. これらの図か らわかるように, エンタルピー変化拈よびェントロピー変 化に, 起電力法の欠点であるグラフ処理などにより值を得 ることによる分散度がやや大きいことが認められるが，y の值によらず, 酸素の相対部分モル量はUの平均原子価に ほぼ依存して拈り，かつ $\mathrm{UO}_{2+x}$ のそれとも比較的よく一 致することが認められた，また，本実験の結果では，平均 原子価の低いところでのエンタルピー変化およびェントロ

(8) S.Aronson and J.Belle: J.Chem.Phys., 29 (1958), 151.

(9) T.L.Markin and R.J.Bones : UKAEA, AERE-R4042,4178 (1962).

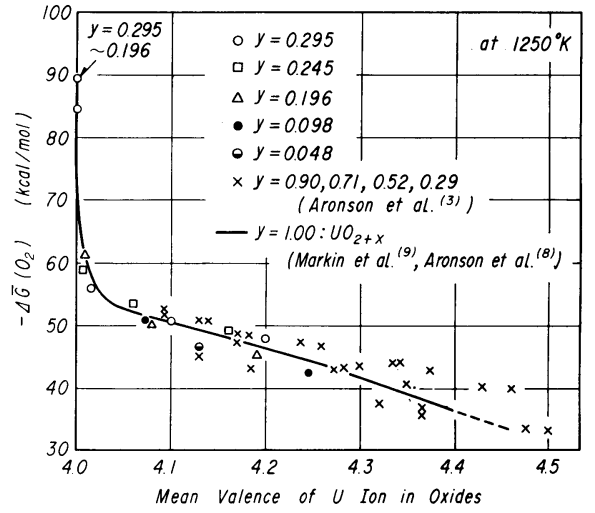

Fig.5 $\Delta \bar{G}\left(\mathrm{O}_{2}\right)$ versus mean valence of $U$ ion in $\left(\mathrm{U}_{y} \mathrm{Th}_{1-y}\right) \mathrm{O}_{2+x}$ and $\mathrm{UO}_{2+x}$

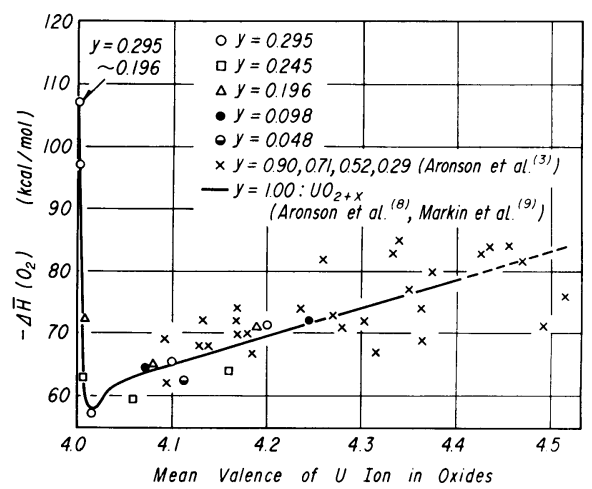

Fig.6 $\Delta \bar{H}\left(\mathrm{O}_{2}\right)$ versus mean valence of $\mathrm{U}$ ion in $\left(\mathrm{U}_{y} \mathrm{Th}_{1-y}\right) \mathrm{O}_{2+x}$ and $\mathrm{UO}_{2+x}$

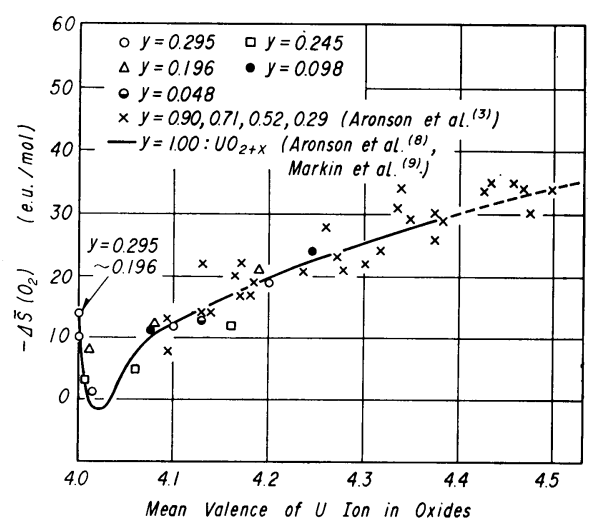

Fig.7 $\Delta \bar{S}\left(\mathrm{O}_{2}\right)$ versus mean valence of $\mathrm{U}$ ion in $\left(\mathrm{U}_{y} \mathrm{Th}_{1-y}\right) \mathrm{O}_{2+x}$ and $\mathrm{UO}_{2+x}$

ピー変化について, $\mathrm{UO}_{2+x}$ の場合と同様, 反転現象を示す ことが観察された。 この反転現象を示し始めるところに対 応する平均原子価の值は, 約 $4.02 \sim 4.01$ であると考えら れる. 反転現象を示す平均原子価以上の領域では, エント ロピー変化が $(9)$ 式の関係をほぼ満足することから, 固溶 体中の酸素の挙動は大部分 $\mathrm{U}^{5+}-\mathrm{O}_{i}^{2-}-\mathrm{U}^{5+}$ 型の複合欠陥で 説明されると考えられるが，平均原子価がそれ以下の領域 
では, $\mathrm{UO}_{2+x}$ の場合の結果 ${ }^{(10)}$ から考えると, 格子位置の 酸素イオンの欠損による空孔の存在が無視出来なくなって るものと考えられる. このことは, 電気伝導度の測定の結 果からも，この領域が単に前述の複合欠陥による取扱いで は, 説明出来なかったことからもらかがえる. しかしなが ら,このように反転現象を示すが，全体としては固溶体中 の酸素の挙動は $U^{5+}$ の濃度に大部分依存していると考えら れ， $\mathrm{Th}^{4+}$ は過剩酸素に対してはほとんど不活性であると 考えられる. 以上のように $\mathrm{UO}_{2}-\mathrm{ThO}_{2}$ 固溶体中の酸素が, $\mathrm{UO}_{2+x}$ 中のそれと同様の挙動を示すことの理由としては, 主として次に挙げる点が考えられよう。

(1) $\mathrm{UO}_{2}$ と $\mathrm{ThO}_{2}$ とが $\mathrm{CaF}_{2}$ 型という同種の結晶構造を 有し，かつ組成に対する格子定数の変化が，ほぼVegard の法則に従らこと(11).

(2) $\mathrm{U}^{4+}$ と $\mathrm{Th}^{4+}$ がそのイオン半径の大きさにおいて差 が少ないこと $\left(\mathrm{U}^{4+}: 1.01 \AA \text {, } \mathrm{Th}^{4+}: 1.06 \mathrm{~A}\right)^{(12)}$

(3) 本実験で取扱ら範囲においては $\mathrm{Th}^{4+}$ の原子価に変 化がないこと.

すなわち(1)，(2)の点よりUイオンと Th イオンとが 固溶体中のカチオン位置でほとんど区別なく位置すること が可能であり，さらに格子定数が Vegard の法則にほぼ従 らことから，イオン間の相互作用が $y$ の值によりほとんど 変化しないことが考兄られ，(3)の点より, 固溶体の酸化 がUイオンの酸化のみに限られることが考えられ，これら のことが, $\mathrm{UO}_{2+x}$ と同様の挙動を示す理由と思われる. こ

(10) R.J.Ackermann, R.J.Thorn and G.H.Winslow : J.Opt.Soc.Am., 49 (1959), 1107.

(11) J.A.Christensen : HW-76559 (1963) .

(12) 桐山, 桐山：構造無機化学, 共立出版, (1966).

(13) T.L.Markin and E.J.McIver:'Third International Conf.on Plutonium, (1965).

(14) T. L. Markin and E.C. Crouch : J. Inorg. Nucl. Chem., $32(1970), 77$.

(15) W.L.Lyon and W.E. Baily: ANS Meeting in Washington, D.C., 1965.
のような現象は, 他に $\mathrm{UO}_{2}-\mathrm{PuO}_{2}$ 固溶体の $11 \sim 30 \mathrm{~mol} \%$ $\mathrm{PuO}_{2}$ の組成の亜化学量論組成から超化学量論組成の両領 域にわたるものについて ${ }^{(13)}$, および $\mathrm{UO}_{2}-\mathrm{CeO}_{2}$ 固溶体の約 $50 \sim 80 \mathrm{~mol} \% \mathrm{CeO}_{2}$ の組成のものを酸素分圧 $0.21 \mathrm{~atm}$ で $900^{\circ} \mathrm{C}$ で処理した場合について ${ }^{(14)}$ 同様に観察されている. これらの固溶体についてもやはり， $\mathrm{UO}_{2}-\mathrm{ThO}_{2}$ 固溶体につ いて前に挙げた諸性質と同様の性質を示すことが知られて いる(12)(15).

以上本実験で取扱った範囲においては前述のよらに, $\mathrm{UO}_{2+x}$ と同様の非化学量論性を有すると考えられるが，y の值が 0.1 以下でUの平均原子価が高い領域では Th イオ ンの固溶体の酸化に対する妨害作用が生ずると考えられる ことが電気伝導度測定の結果から示唆されており, この固 溶体の非化学量論性をさらに明らかにするには, Th 濃度 のさらに高い領域扰よびその高酸化状態での検討が必要で あると考えられる。

\section{VI. 総 括}

(1) 下記に示すような固体電池を構成し， $900 \sim 1050^{\circ} \mathrm{C}$ の温度範囲で測定し，安定な起電力值が得られた.

$\mathrm{Pt} / \mathrm{Air}\left(\mathrm{P}_{\mathrm{O}_{2}}=0.21 \mathrm{~atm}\right) / \mathrm{ZrO}_{2}(+15 \mathrm{~mol} \% \mathrm{CaO}) /$

$\left(\mathrm{U}_{y} \mathrm{Th}_{1-y}\right) \mathrm{O}_{2+x} / \mathrm{Pt}$

$\mathrm{Pt} / \mathrm{Ni}, \mathrm{NiO} / \mathrm{ZrO}_{2}(+15 \mathrm{~mol} \% \mathrm{CaO}) /\left(\mathrm{U}_{y} \mathrm{Th}_{1-y}\right) \mathrm{O}_{2+x} / \mathrm{Pt}$

(2) 上記の電池により測定される起電力值およびその温 度依存性に関する結果を用いて，固溶体中の酸素の溶解の 相対部分モル量が計算されたが，それらの值とUの平均原 子価との関係を検討した結果, $x<0.029,0.048 \leq y \leq 0.295$ の範囲では，ほぼ $\boldsymbol{y}$ の值によらない相関が存在した。

(3) 以上の結果から, $\mathrm{UO}_{2}-\mathrm{ThO}_{2}$ 固溶体の非化学量論性 は $\mathrm{UO}_{2+x}$ のそれとほぼ同様のものであると考兄られる.

本実験の遂行にあたり，ご協力頂いた野沢 博工学士に 謝意を表します。 